\title{
Mathematical Modeling of the Strategy of the Early Islamic Wars
}

\author{
Fouad Abiad \\ Department of Human Sciences, Cadi Ayyad University, Morocco \\ Fou_dence@uca.ma
}

\begin{abstract}
A mathematical model is a description of a system using mathematical concepts and language. The process of developing a mathematical model is termed mathematical modeling. Mathematical models are used in the natural sciences (such as physics, biology, earth science, chemistry) and engineering disciplines (such as computer science, electrical engineering), as well as in the social sciences (such as economics, psychology, sociology, political science).

The main activities involved in this procedure are observation followed by mathematical modeling; simulation, analysis, optimization and back to observation, Mathematics has been applied to all sciences; and religious and military sciences are no exception, and mathematics can be used highly to design different war operations and solve battlefield equations to gain relative or absolute superiority over the enemy. We can also see clearly the application of mathematics in the Game Theory of war in abundance. In this applied research, conducted in a library method, the challenges between the army of Amir al-Mu'minin, 'Alī ibn Abī Țālib (as) and the army of Mu'āwiya ibn Abī Sufyān in the Battle of Siffin have been modeled using Game Theory and the strategies of each of these two fronts are compared.
\end{abstract}

\section{Keyword: Strategy; Modeling; Mathematical}

\section{Introduction}

There are many definitions of science (Popper, 1935; Kuhn, 1962, 1965; Lakatos, 1970), but all of them refer to a body of knowledge obtained through a particular method based on the observation of the physical world, linked to systematically structured reasoning, strategies by which general principles and laws are deduced. That particular method is the "Scientific Method", defined by the Oxford English Dictionary as "...the procedure..., consisting in systematic observation, measurement, and experiment, and the formulation, testing, and modification of hypotheses." In the above statements there are two core ideas which are relevant here and that derive directly from what science is: the first one is that any scientific activity requires measurements and thus, quantification of real magnitudes. The second is that any scientific activity makes sense only if it allows us to gain "knowledge"; that is understanding, predicting and control. In science these goals are achieved through the building of models and theories. Both serve, with different degrees of generality, to explain the observed facts and predict with high probability the evolution and behavior of natural systems. 
The mathematical models not only help us to understand the system, but also are instrumental to yield insight into the complex processes involved in biological systems by extracting the essential meaning of the hypotheses (Wimsatt, 1987; Bedau, 1999; Schank, 2008) and allows to study the effects of changes in its components and/or environmental conditions on the system's behavior; that is, they allow the control and optimization of the system.

Mathematical modeling was made possible as early as the 17th century, but it is with today's techniques that it has become available to natural (and even social) scientists. There is already an ample evidence of the value and usefulness of the modeling approach in solving relevant problems in biosciences. However, in order to place modeling at the core of biological research it is necessary for the new generations of bio-scientists to be prepared to be able to build models. Currently, there are two conditions that must be met for this trend to accelerate. First, it is a matter of fact that the ecumenical nature of the training required by the modeling task in biosciences has impaired this desired evolution. The paradigm shift that involves the incorporation of the integrative approach requires shaping and expanding the training base of the new bioscience graduates with elements that include a broad and solid background in mathematics, thermodynamics, and scientific computing, among other new disciplines, in addition to the classic as chemistry, genetics and bioinformatics. Mathematical modeling of bioprocesses also has severe limitations for development and generalization because of the lack of training in math observed in many bioscience postgraduates. It is our view that the best way to overcome this flaw is through the inclusion of two elements that are, at least not well developed in the curricula of the biosciences graduates, if not absent. One is the appropriate, and properly adapted mathematical contents, which could deal with the normally underdeveloped mathematical thinking of the students. There is some discussion as to what contents and to what extent the biosciences students should be exposed to. But what seems unavoidable is the fact that the biological scientist of the XXI century should be fluent not only in mathematics (in statistics and also in other mathematical concepts such as ordinary differential equations) but also in modeling techniques. Fortunately, there is an increasing awareness in this regard and some material is already available to fill this gap.

While this study will attempt to extract prominent indices from the text of the history of the early wars of Islam with the focus on the battle of Siffin, and to be compared with the concepts and algorithms of the War Game, it is hoped that this effort will provide a framework for similar further studies; but it is clear to note that Game Theory is the result of human experiences and computations, and naturally has conceptual and computational errors, and sometimes it may not be completely mixable with hidden criteria in the religious teachings that are based on fixed and unchangeable divine traditions. In describing the profits and losses, what exists in the literature of this field is different from what is derived from the religious doctrine of the concept of profit and loss (especially with regard to the concept of eternal reward).

Mathematical modeling is a principled activity that has both principles behind it and methods that can be successfully applied. The principles are over-arching or meta-principles phrased as questions about the intentions and purposes of mathematical modeling. These meta-principles are almost philosophical in nature. We will now outline the principle. Modeling is considered from a cognitive perspective (Borromeo Ferri, 2006). Greefrath and Vorhölter (2016) explain that this approach is seen as a kind of meta-perspective, because it is about analysing and understanding the cognitive procedures that take place in modeling problems. Not only are the different steps of problem-solving analysed, but also the students' cognitive processes. In this perspective, different descriptive models of modeling processes are developed, such as individual modeling paths that can be contrasted with the idealized modeling cycle.

What will be explored in this research lies in the range of the sīrat Alawite and the teachings of Nahj al-Balāghah. We do not intend to view the material presented as a whole religion, but in terms of the conditions and circumstances of Amir al-Mu'minin's life, this text will be one of the most comprehensive and helpful guidelines. 
The research of narratives on topics covered by predefined narrow keywords can, to a certain extent, clarify the dimensions of the problem. But in areas similar to what will be dealt with in this research, it is not possible to find a point simply by looking for keywords, but rather we should look at it in a scientificanalytical way.

Many types of modeling implicitly involve claims about causality. This is usually (but not always) true of models involving differential equations. As the purpose of modeling is to increase our understanding of the world, the validity of a model rests not only on its fit to empirical observations, but also on its ability to extrapolate to situations or data beyond those originally described in the model. One can think of this as the differentiation between qualitative and quantitative predictions. One can also argue that a model is worthless unless it provides some insight which goes beyond what is already known from direct investigation of the phenomenon being studied.

Strategic science approaches with the book of war and jihad by Amir al-Mu'minin (AS) can open new horizons on this subject. What have been the origins of the wars, what strategies did Amir (AS) use, and what fundamental assumptions have shaped the prophet's strategy and security doctrine, are these teachings analyzable in the form of Games Theory as a human and conventional artifact? Can it support the strategic decision-making and decision-helping in the war?

The main purpose of the present study is to provide a model that paves the way for future research in the field of Game Theory and its applications in political and international relations based on Islamic teachings.

\section{Theoretical Review}

\section{A. The recognition of the strategy concept}

Strategy is a governmental issue that has exited from the fence of military force and power and includes politics, culture, economics and society. In other words, strategy in general means the technique of harmonizing the cultural, political, economic, religious, psychological, military capabilities of a nation or country and its application to realize the national goals; therefore, in any time and place conditions it can be mentioned and applied(Shetreet, 1999).

Once the mathematical modeling studies have been broadly characterized, and their purpose has been determined, it is important to gain a better understanding about some of the terms used to describe the technical aspects of the model used in a study. For example, has heterogeneity among different individuals been incorporated, or what simulation methods were used to obtain the model results? The following list includes some of the most frequently used terms in mathematical modeling studies in various fields of epidemiology.

In addition to providing a useful common terminology for public health specialists and mathematical modelers, the description of different model types and other terms defined in the glossary facilitate interpretation of the results of mathematical modeling studies and inform their incorporation into the guideline development process. As a first step, one needs to identify whether a particular research question, eg, the evaluation of public health programs, long-term effectiveness or comparative effectiveness, can be investigated using a model. Next, it will be necessary to assess whether existing mathematical modeling studies are appropriate to inform or support a research question or recommendation. We identified four comprehensive frameworks of good modeling practice. These frameworks cover items such as relevance, conceptualization of the problem, or model structure. Questions such as whether the model population is relevant, the variables represent the desired health outcomes, the necessary heterogeneity is taken into consideration, the time horizon is appropriate, or the assumptions justified can help in the 
assessment of mathematical modeling studies. Other items concern validity or consistency, ie, the performance of the model according to its specifications. The model should also consider uncertainty with regard to the structure, parameters, and methods. Finally, credibility, which takes a number of these items into account, can then be used as the central concept for guideline developers to address the appropriateness of a mathematical modeling study for providing evidence for a specific question, as illustrated in the following example.

The military strategy, according to Colonel Arthur Lykke, is to set military goals, set up military theories to achieve goals, and use military resources to execute theories. When each of these basic and fundamental elements conflict with other elements, national security will be at risk.

There is no consensus among the scholars of international relations and sociologists in the division of all kinds of military strategies. Some divide these strategies in relation to the historical evolution of the strategy into traditional and modern strategies. Some, according to the battlefield, divide it into terrestrial, aerospace, and marine strategies. The third group also identifies strategies with five characteristics, namely: direct threat, indirect threat, advance or indirect actions through surprise, traditional destruction and partisan strategy.

\section{B. Game Theory in the occurrence of war}

Game Theory has been created from the community of logic and mathematics and in some way relies on the abstract reasoning. The centrality of this theory has been established on the rationality of the actors involved in the game. That is, players compete in the game and try to get the highest points from the other party (meaning that people act due to the profit and cost basis). However, individuals can act irrationally and emotionally in conflict situations. But game theorists believe that people who participate in the game act by rational calculation and by guessing the actions of the other party and try to gain points from the other side (Users, 2010).

In Game Theory, each player seeks a situation in which each of the competing parties performs evaluations and measures to prevent the success of the other party. The difference between a game and a real conflict situation is that the game is based on predetermined conditions, while in a conflict situation there is not necessarily a predetermined situation (Ibid, 1397: 8).

Player: people who influence each other's decisions are called players, people who feel that there is an interdependence between their decisions and their actions and they are aware of that interdependence. Players who interact with a particular player are called the "opponent" of that player.

\section{The reasons for the occurrence of the Siffin battle}

When Amir al-Mu'minin (AS) came to the caliphate, Mu'āwiya ibn Abī Sufyān was governor of Syria. The second caliph had appointed him as the governor of Syria in 18 AH (Ibn Athir, 1408, v. 2: 172), and during the caliphate of the third caliph, Mu âwiya remained in the position of governor of the Syria (Ibn Asakir, $1421 \mathrm{AH}$, vol 62: 81). Imam Ali (AS) decided to send Abdullah ibn Abbas as the governor of Syria; so he wrote a letter to Mu'āwiya in which he asked him to come to Medina with the rich of Syria and make allegiance to Imam (as), but Mu'āwiya refused to make allegiance to Imam Ali (AS); rather he mentioned the avenge of "Uthman's blood. 
Amir al-Mu'minin Ali (AS) in a letter addressed Mu'āwiya and wrote:

"The people's allegiance to me is a public allegiance, whether those who were present in Medina at the time of allegiance or those who were in Syria, Basra and other cities. Everyone knows that I haven't kill 'Uthman to deserve retaliation, and 'Uthman's heirs deserve to revenge for his blood more than you, but you are one of those who opposed him and at the time he asked your help and you could help him, you didn’t help him until he was killed." (Ibn Abi al-Hadīd, nd, Volume 3: 89).

Mu'āwiya did not respond to Imam's letter (Balādhurī, 1996, v. 2: 211) and he gathered the people in the mosque and told them: "I am the governor of 'Umar ibn al-Khattāb and also 'Uthmān ibn 'Affān over the people of Syria. I am the legal guardian for the blood of the caliph who was killed oppressed. What do you think about the blood of 'Uthmān? All the people declared their support in revenge of the blood of the Third Caliph, and this was a practical response from Mu'âwiya to the Imam. After the end of the battle of the Jamel war, Imam Ali (AS) moved the center of the caliphate to Kufa and tried to persuade Mu āwiya to obey Imam Ali (AS) (Ibn 'A'tham, nd, vol. 2: 211), but after he was convinced Mu'āwiya has no intention of allegiance and obedience, and the elders of Kufa are defending Imam in the war against Mu'āwiya, he invited the people to jihad in a public sermon.

In the prediction part of the scientific method we exercise our models to tell us what will happen in a yet-to-be-conducted experiment or in an anticipated set of events in the real world. These predictions are then followed by observations that serve either to validate the model or to suggest reasons that the model is inadequate. The last point clearly points to the looping, iterative structure apparent in Figure 1.1. It also suggests that modeling is central to all of the conceptual phases in the elementary model of the scientific method. We build models and use them to predict events that can confirm or deny the models. In addition, we can also improve our gathering of empirical data when we use a model to obtain guidance about where to look.

\section{Collecting the Corps}

Amir al-Mu'minin (AS) called on the elders of the Companions, who were from Anșār and Muhājirān (i.e. emigrants), and asked them to comment on going to Syria, and wrote a letter to Ibn Abbas, the Governor of Basra, to invite the people of Basra to accompany him, then many people of Basra came to Kufa with Ibn 'Abbas at the invitation of the Imam (AS). He also wrote a letter to Mikhnaf ibn Sulaym, the ruler of Isfahan, and called him to join the Imam's army (Ibn Muzāḥim, 1403 AH: 115) and Imam also ordered the fighters to move to Nakhliya, a military camp in Kufa. Mu'āwiya, who had also decorated the pulpit of the Syria Mosque with the bloody clothing of the Third Caliph, while many were crying around him, prepared the Syria people to confront the Iraqi army.

\section{E. Siege of Euphrates}

At first the Mu'āwiya's army reached the Euphrates River and denied the Kufa army access to the Euphrates to weaken and destroy them. Imam (AS) sent Musayyib b. Rabi' al-Riyahi and Sa'sa'a b. Sawhan, saying: "go to Mu'āwiya and tell him, 'your soldiers have stood between us and the water and have blocked our access to water, if we were to get water earlier than you and build our camp there, we would not deny your access to the water, Stop blocking the water so that our army and yours use it equally, otherwise we have to fight over water (Ibn 'A'tham, $1411 \mathrm{AH}, \mathrm{v} .3: 5-6)$.

For example, when modeling the flight of an aircraft, we could embed each mechanical part of the aircraft into our model and would thus acquire an almost white-box model of the system. However, the computational cost of adding such a huge amount of detail would effectively inhibit the usage of such a 
model. Additionally, the uncertainty would increase due to an overly complex system, because each separate part induces some amount of variance into the model. It is therefore usually appropriate to make some approximations to reduce the model to a sensible size. Engineers often can accept some approximations in order to get a more robust and simple model. For example, Newton's classical mechanics is an approximated model of the real world. Still, Newton's model is quite sufficient for most ordinary-life situations, that is, as long as particle speeds are well below the speed of light, and we study macro-particles only.

Assessing the scope of a model, that is, determining what situations the model is applicable to, can be less straightforward. If the model was constructed based on a set of data, one must determine for which systems or situations the known data is a "typical" set of data.

The question of whether the model describes well the properties of the system between data points is called interpolation, and the same question for events or data points outside the observed data is called extrapolation.

As an example of the typical limitations of the scope of a model, in evaluating Newtonian classical mechanics, we can note that Newton made his measurements without advanced equipment, so he could not measure properties of particles travelling at speeds close to the speed of light. Likewise, he did not measure the movements of molecules and other small particles, but macro particles only. It is then not surprising that his model does not extrapolate well into these domains, even though his model is quite sufficient for ordinary life physics.

\section{F. Laylat al-Harir}

Laylat al-Harir was a difficult and decisive night. The two armies fought in that night, many soldiers of both sides were killed. According to Minqari ${ }^{1}$, in that night, there was no sound heard except the sound of hitting the swords (Ibn Muzāhim, 1403 AH: 475). Ibn Miskawayh described that night: "They fought in that night, so hard that spears broke and no arrow was left in quivers and then they began fighting with swords." (Ibn Miskawayh, 1379 H.S. v. 1: 535). The soldiers of Imam Ali (a) were close to victory, until Ash'ath ${ }^{2}$ rose among the warriors of Kindis tribe, gave a sermon and with a peace-making tone, asked for stopping more bloodshed. According to hadiths, as soon as Mu'āwiya was informed about the sermon of Ash'ath, ordered to put the Qur'ans on the spears and shouted the motto of "no verdict except the verdict of Allah". (Ibn Muzāḥim, 1403: 480-481 and Dinvari, 1960: 188-189).

\footnotetext{
${ }^{1}$ Nașr b. Muzāhịim b. Sayyār 'Ațtāar Minqari is from Iraq and one of the Shiite historians in the second century. Sheikh Tūsī believes that he is one of the companions of Imam Bāqīr (AS).

2 Ash 'ath ibn Qays kindi was the head of the Kindah tribe and the governor of Amir al-Mu'minin (AS) in Azerbaijan. Ash 'ath was in the army of Imam in the battle of Siffin but he had relationship with Mu'äwiya during the war and on the night of Laylat al-Harir, when Imam was on the verge of victory, he began to urge soldiers stop the battle and prepared the ground for Mu'āwiya to put the Quran on the spears. Ash'ath had an important role in imposing the conversation to Imam and he also forced Imam to choose Abu Musa Ash 'ari, who was an idiot person, for the conversation. He also played an influential role in inciting the Khawarij against Imam (Balādhurī, 1966, v. 2, 296 and Tabari, 1967, v. 4: 561.) Also his daughter was Ja'adeh, the wife of Imam Hasan (AS), who poisoned martyred him. (Saduq, 1395, v. 2: 546.) His son was Muhammad ibn Ash'ath who handed Muslim ibn Aqil over to Ibn Ziyad and he was in the army of Kufa and stood in front of Imam Hussein (AS) (Abu Mikhnaf, 1417: 134)
} 


\section{G. Imam Ali's (AS) reaction to his troops}

After the motto of "no verdict except the verdict of Allah" was issued in the battlefield, the people demanded Imam (AS) to answer them, while Malik Ashtar, army's commander, had no idea but to continue the war (Ibn Muzāhim, 1403: 478). Imam Ali (AS) arose and said, "I always wanted to carry on my job with you and be with you ... yesterday I was your commander and today I am your follower, yesterday I was banning you and today you are banning me. You are interested in the fleeting world, and I cannot make you do something that is unpleasant to you." (Ibid: 482-484).

Historians disagree on the death toll of the two corps in the battle of Siffin, some have said: Seventy thousand people have been killed, including forty-five thousand men from the Mu'āwiya's army and twentyfive thousand from Imam Ali's army (Ibn Abi al-Hadid, nd. v: 1).

\begin{tabular}{|l|c|}
\hline \multicolumn{1}{|c|}{ The battle of Siffin } \\
\hline \multicolumn{1}{|c|}{ Year 37 AH } & Time \\
\hline \multicolumn{1}{|c|}{ A region called Siffin } & Place \\
\hline The end of the war by accepting arbitration & Result \\
\hline $\begin{array}{l}\text { The disloyalty and unacceptance of the } \\
\text { caliphate of Imam Ali (AS) by Mu'āwiya } \\
\text { and declaration of independence in the } \\
\text { governorate of Syria }\end{array}$ & $\begin{array}{c}\text { Reason of the } \\
\text { war }\end{array}$ \\
\hline $\begin{array}{l}\text { Army of Imam Ali (AS) - Army of Mu'āwiya } \\
\text { ibn Abu Sufyān }\end{array}$ & Fighters \\
\hline
\end{tabular}

\section{Research Methodology}

This research is a library research, but from an objective point of view, the research is practical, as it tries to put the results of this research into practical use and, with the help of its results, solve the problems of the organization.

\section{The Strategies of Mu'āwiya and Imam Ali (AS)}

We put the strategies of Mu âwiya in set S1 and the strategies of Imam Ali (AS) in set S2:

$A_{1}=S_{1}$ ) blackmail Imam Ali (as) to take over the rule of Syria and Egypt,

$A_{2}$ ) pretending oppressed and avenging the blood of 'Uthmān

$A_{3}$ ) an attempt to deceive public opinion,

$A_{4}$ ) bribing the commanders of Imam Ali's army, 
$A_{5}$ ) direct war,

$\left.A_{6}\right)$ an attempt to isolate Imam Ali (AS) in the minds of the people,

$A_{7}$ ) the use of the sacred and the Qur'an on bayonet,

$A_{8}$ ) applying the influence in imposing the blind negotiator on Imam Ali (as) for the judgment,

$A_{9}$ ) making a discord among the troops of Imam Ali (as),

$A_{10}$ ) a psychological war.

$I_{1}=S_{2}$ ) Rejecting Mu'āwiya's conditions for governing on Syria and Egypt,

$I_{2}$ ) trying to seduce public opinion,

$I_{3}$ ) trying not to enter into war,

$I_{4}$ ) public jihad against Mu'āwiya,

$I_{5}$ ) summoning Basra and Isfahan troops,

$I_{6}$ ) warlike proper decoration of the corps,

$I_{7}$ ) motivating many in the army with fiery speeches,

$I_{8}$ ) using resourceful, bravery and warrior commanders,

$I_{9}$ ) direct and brave presence on the battlefields to stimulate the sentiments of the soldiers,

$I_{10}$ ) observing the ethics in all war scenes,

$\left.I_{11}\right)$ acting rightly during the war.

\section{Consequences:}

The amount of win or loss and what the players earn at the end of a game is called "consequence." The consequence can be money, income, privilege, and so on. At this stage, the possible consequences of each option (strategy) must be estimated. The key question in each game is that which strategy should be used by each player to achieve the most possible consequence; the answer is the "balance point" of the game. But what is the "balance point "? 


\section{The balance:}

Whenever a player uses a strategy that is the best answer to the strategy chosen by other players, then the combination of the chosen strategies is called "game balance". The balance point of the game is a combination of players' strategy that happens in practice. In balance, players do not necessarily get the most consequences. This can be due to conflict of interests or lack of knowledge of players. In fact, one of the main goals of Game Theory is to find the same point of balance for each game.

\section{The utility function for game theory}

The $\mathrm{i}^{\text {th }}$ player, who is involved in decision making, must fight against his rival for maximum revenue. We measure the income of $i^{\text {th }}$ player based on the utility function for that player. In this study, utility function model is calculated based on the cost-benefit analysis.

According to the rational decision-making theory, using the cost-benefit analysis model is nowadays common in macro-political decision-making. In this way, all the costs and benefits of a decision are evaluated and analyzed, and then they reach a decision(Guzzini, 2000).

There are many definitions for cost-benefit analysis. For Bremen, this type of analysis is an indicator weighting method for decision making and acts as a scale. That is, all the positive elements of one project (benefits) have been put in one balance sheet, and all the negative elements and costs (costs) have been put in the other one, and the heavier will be the winner. Cost-benefit analysis is a decision-making logic that operates on the basis of calculating the possible outcomes of different decision options (Ibid: 20). Costbenefit analysis answers five basic questions:

1) How much direct benefits will be obtained from this expense?

2) What indirect benefits will come from this cost?

3) Whether the obtained benefits are greater than the spent costs?

4) What will happen if the costs are not done?

5) Is there a less expensive option if this is necessary?

This analytical approach helps to determine the best decision for maximizing benefits against minimum costs.

\section{Modeling the utility function}

In 2011, Berman presented the following formula for utility function in the following form:

For the utility function can quantitatively predict the everyday war, this function considers three aspects: Human Cost (H), Economic Cost (E) The gained or lost socio-political Influence Value (I) (Berman et al., 2011). 


\section{Human resources:}

- Losing the loyalty of the corps' forces of the loser side

- Paying pensions to the families of those killed in the war

- Elimination of effective human resources in social and defense activities

\section{Economic aspect:}

- losing Taxes on areas dominated by the Kufa Corps including the territories of Hejaz, Yemen, Arab Iraq, Iran and Egypt, and Syria for the army of Syria.

- Problems arising from the imposed cost of war

\section{Socio-political influences:}

- Losing loyalty of the dominated territories, which was Syria for the Syria Corps, and Hijaz lands for the Kufa Corps, including Mecca and Medina, the Yemeni land, the Arab Iraqi land including Kufa and Basra, the Iranian land including Azerbaijan, Tabaristan, Khorasan, Ray, Sistan, Isfahan and Ahwaz as well as the land of Egypt.

- Reducing the geographical-political boundaries of the loser

Expenses incurred include:

\section{Human resources:}

- Obtaining the loyalty of the loser corps forces

- Receiving taxation from the new areas under control

- Gaining effective human resources in social and defense activities

\section{Economic aspect:}

- Receiving taxation from areas under control which was for Kufa Corps in the territories of Hejaz, Yemen, Arab Iraq, Iran and Egypt, and for the Syria Corps in the Syria.

- Obtaining war trophies.

\section{Socio-political influences:}

- Obtaining the loyalty of the dominated territories which was Syria for Syria; and for Kufa it was Hejaz including Mecca and Medina, Yemen, Arab Iraq including Kufa and Basra, Iran including Azerbaijan, Tabaristan, Khorasan, Ray, Sistan, Isfahan, Ahwaz and the land of Egypt.

- Expanding the geo-political boundaries of the victorious side and thus becoming a global superpower. 
According to what Berman and his colleagues have done (2011), the benefits of war can be calculated by:

(1) $u_{i}=\alpha_{H}\left(H_{G}-H_{L}\right)+\alpha_{E}\left(E_{G}-E_{L}\right)+\left(1-\alpha_{H}-\alpha_{E}\right)\left(I_{G}-I_{L}\right)$

In relation (1), $H_{L}$ and $H_{G}$ respectively represent the gained and lost costs of human resources resulting from the war.

$E_{L}$ and $E_{G}$ represent the economic value gained and lost by the war, $I_{L}$ and $I_{G}$ are the value of sociopolitical influences gained and lost by the war. $\alpha_{E}$ and $\alpha_{H}$, respectively, represent the weight of economic and human factors in the decision making of the $\mathrm{i}^{\text {th }}$ player, with values ranging from zero to one: $0 \leq \alpha_{H}, \alpha_{E} \leq 1$

Two things that should be considered in the model are that, first, the calculations toward time must be dynamic with respect to changes in the unit of time, and second, there must be a decision maker's opinion's consequent. Accordingly, and for dynamism toward time, we consider a coefficient for different times, indicating the importance of each time in the range 0 to t. The coefficient $\delta$ is assumed between 0 and 1 for this aim and if the exponentiation $t$ is considered for this coefficient, the coefficient value for the utility function will be different and time dependent. In addition, the coefficient $\beta$ is considered as the risk coefficient to reach the utility (Sherman, 2015).

In 2015, Sherman, in his article, concluded that to make an important decision, the opinions of different people, each aiming to maximize revenue, are influential. Therefore, the $i^{\text {th }}$ player must choose a weight for each of the ideas and consider it in the calculations. With this description, the utility value is calculated from the following relation:

$$
\begin{gathered}
U_{i}(t)=\left(\sum _ { t = 1 } ^ { T } \delta ^ { t - 1 } \left[\frac{\sum_{j=1}^{N} \gamma_{j} \alpha_{H j}}{N}\left(H_{G t}-H_{L t}\right)+\frac{\sum_{j=1}^{N} \gamma_{j} \alpha_{E j}}{N}\left(E_{G t}-E_{L t}\right)\right.\right. \\
\left.\left.+\frac{\sum_{j=1}^{N} \gamma_{j}\left(1-\alpha_{H j}-\alpha_{E j}\right)}{N}\left(I_{G t}-I_{L t}\right)\right]\right)^{1-\beta}
\end{gathered}
$$

Another point to keep in mind is that each of the six economic values mentioned can have $\mathrm{M}$ subset and have different dimensions. As a result, relation (2) is rewritten as follows: 


$$
\begin{gathered}
U_{i}(t)=\left(\sum _ { t = 1 } ^ { T } \delta ^ { t - 1 } \left[\frac{\sum_{j=1}^{N} \gamma_{j} \alpha_{H j}}{N} \sum_{k=1}^{M}\left(H_{G k t}-H_{L k t}\right)+\frac{\sum_{j=1}^{N} \gamma_{j} \alpha_{E j}}{N} \sum_{k=1}^{M}\left(E_{G k t}-E_{L k t}\right)\right.\right. \\
\left.\left.+\frac{\sum_{j=1}^{N} \gamma_{j}\left(1-\alpha_{H j}-\alpha_{E j}\right)}{N} \sum_{k=1}^{M}\left(I_{G k t}-I_{L k t}\right)\right]\right)
\end{gathered}
$$

Although the $\mathrm{i}^{\text {th }}$ player is more commonly known as one side of the conflict, he can be any player or group. Different actors differ significantly in how we evaluate the weights of $\alpha_{H}, \alpha_{E}$ and $\alpha_{H}-\alpha_{E}-1$ in terms of human life value, economic value and influence value, respectively.

\section{Utility table gained for hypothetical war:}

In the table below, we check the utility function in the states of victory of either Kufa or Syria $(\mathrm{V})$, their defeat $(\mathrm{F})$, peace and acceptance of the terms and conditions of the parties' treaty $(\mathrm{P})$, and finally staying

\begin{tabular}{|c|c|c|c|}
\hline & $\begin{array}{l}\text { The utility gained for Kufa corps } \\
\text { (player 2) }\end{array}$ & $\begin{array}{l}\text { The utility gained for Syria corps } \\
\text { (player 1) }\end{array}$ & \\
\hline & $\left\{\sum_{t=1}^{T}\left(\begin{array}{c}\delta^{t-1}{ }_{2}\left[\alpha_{H 2}\left(-H_{L t}\right)\right. \\
+\alpha_{E 2}\left(-E_{L t}\right) \\
\left.+\left(1-\alpha_{H 2}-\alpha_{E 2}\right)\left(-I_{L t}\right)\right]\end{array}\right)\right.$ & $\left\{\sum_{t=1}^{T}\left(\begin{array}{c}\delta^{t-1}{ }_{1}\left[\alpha_{H 1}\left(H_{G t}-H_{L t}\right)\right. \\
+\alpha_{E 1}\left(E_{G t}-E_{L t}\right) \\
\left.+\left(1-\alpha_{H 1}-\alpha_{E 1}\right)\left(I_{G t}\right)\right]\end{array}\right)\right\}^{1-f}$ & $\begin{array}{l}V_{1} \\
F_{2}\end{array}$ \\
\hline & $\left\{\sum_{t=1}^{T}\left(\begin{array}{c}\delta^{t-1}{ }_{2}\left[\alpha_{H 2}\left(H_{G t}-H_{L t}\right)+\right. \\
\alpha_{E 2}\left(E_{G t}-E_{L t}\right)+ \\
\left(1-\alpha_{H 2}-\alpha_{E 2}\right)\left(I_{G t}-I_{L t}\right)\end{array}\right)\right.$ & $\left\{\sum_{t=1}^{T}\left(\begin{array}{c}\delta^{t-1}{ }_{1}\left[\alpha_{H 1}\left(H_{G t}-H_{L t}\right)\right. \\
+\alpha_{E 1}\left(E_{G t}-E_{L t}\right) \\
\left.+\left(1-\alpha_{H 1}-\alpha_{E 1}\right)\left(I_{G t}-I_{L t}\right)\right]\end{array}\right)\right.$ & $P$ \\
\hline$\alpha_{H_{1}}$ & $\left\{\sum_{t=1}^{T}\left(\begin{array}{c}\delta^{t-1}{ }_{2}\left[\alpha_{H 2}\left(H_{G t}-H_{L t}\right)+\right. \\
\alpha_{E 2}\left(E_{G t}-E_{L t}\right)+ \\
\left.\left(1-\alpha_{H 2}-\alpha_{E 2}\right)\left(I_{G t}-I_{L t}\right)\right]\end{array}\right)\right.$ & $\left\{\sum_{t=1}^{T}\left(\begin{array}{c}\delta^{t-1}{ }_{1}\left[\alpha_{H 1}\left(-H_{L t}\right)+\right. \\
\alpha_{E 1}\left(-E_{L t}\right)+ \\
\left.\left(1-\alpha_{H 1}-\alpha_{E 1}\right)\left(-I_{L t}\right)\right]\end{array}\right)\right\}^{1-\beta_{1}}$ & $\begin{array}{l}F_{1} \\
V_{2}\end{array}$ \\
\hline & 0 & 0 & $C$ \\
\hline
\end{tabular}
in the former position and continuing political disputes $(\mathrm{C})$.

respectively, are the coefficient of human value, coefficient of economic value, coefficient of different times' importance, and coefficient of war risk for the Syria Corps (Player 1). Indicators 2 are used for the Kufa Corps (Player 2). Given that in the event of a war between the two armies and defeat, the loser will not gain any human, economic, and socio-political value, so the value of $H_{G t}, E_{G t}$ and $I_{G t}$ is set at zero. Situations 1 to 3 occur when one of the two corps prefers the strategy of starting a war to the strategy of not starting a war. Also, case 4 represents a situation in which the two armies consider the strategy of not starting a war rational. If the strategy of starting a war, for one of the states 1 to 3 , has a favorable outcome for one of the parties, the player will adopt one of the strategies for starting or not starting the war, depending on the 
likelihood of that happening. These possibilities can determine the political positions of the players in the Islamic society of that time regarding their military power. We conclude from these states that if a player wants to avoid a war, he or she must try to keep the favorable value of starting the war for the opposite side in each of the 1 to 3 as negative, or keep the likelihood of negative favorability in the event of a war for the opposite side (the negative utility would be one of the states 1 to 3). It is also important to note that the end of a war can be terminated in a state of equilibrium that is a prelude to the start of the next war, or that one of the parties involved in the war reaches a level of negative desirability that justifies a new war for him.

\section{Conclusion}

The understanding of the system through the use of the mathematical tools that allow the description and analysis of the complex systems can help to deepen the knowledge of the structure, properties and dynamic behavior of the system. However, the collaboration with experienced mathematicians is required for analyses such as the choice of the proper numerical methods, and the selection of the valid simplifications of complicated models. This is the area where most of the typical modeling projects develop: the fertile interface among established disciplines such as cellular biology, biochemistry, genetics and mathematics, and others. In this task all parties are benefited from valuable insight from the interdisciplinary experience. Modeling implies the definition of the model's objectives, and the curation of the available information. It facilitates not only the finding of previously unsuspected areas of exploration, but the proposition of new questions that were not at all evident from the reductionist approach. The systematic practice of modeling in this context also naturally facilitates the fusion of scientific disciplines; this unifying tension is felt not only among biological specialties (e.g., biochemistry, cell biology, microbiology, and genetics) but also with other (seemingly) distant ones, as operational research, computer science and mathematical analysis.

The most important thing to do when modeling utility function is to estimate the benefits and losses resulted from starting and even continuing a war. What prevents the start of a war is called the cost of war, and what drives the opposition and its politicians toward war is the benefit of the war. So we should try to estimate the real costs and benefits. Therefore, it is necessary to estimate the costs and benefits of war in a scientific context. War involves the costs and benefits of human, economic, or other profits that will exist for the winner (loser) if he wins (loses). Estimating each of these points is essential to starting or continuing a particular war.

\section{References}

Abu Mikhnaf Kufi, Lut ibn Yahya, 1417 AH. Waqaa al-Taf, Scholar and Editor: Muhammad Hadi Yousefi Gharavi, Third Edition, Islamic Publications Office, Qom.

Balādhurī, 'Aḥmad ibn Yaḥyā, 1996 A.D. Jamal min Ansab al-Ashraf, Inquiry: Soheil Zakar and Riyadh Zarkeli, Dār al-Fikr, Beirut.

Berman, E., Shapiro, J.N. and Felter, J.H. 2011 A.D. "Can Hearts and Minds Be Bought the Economics of Counterinsurgency in Iraq", Journal of Political Economy, Vol. 119No. 4, pp. 766-819.

B. O'neill. nd. "Game Theory Models of Peace and War"

Guzzini, S. (2000). A Reconstruction of Constructivism in International Relations. European Journal of International Relations, 6(2), 147-182.

Ibn Abi al-Hadid, nd. Description of Nahj al-Balāghah, research by Muhammad Abu al-Fazl Ibrahim, Dār İhyā al-Turāth al-'Arabì, Beirut. 
Ibn Asākir, Ali ibn Hassan. 1421 AH. History of Damascus, Inquiry by Abi Abdullah Ali Ashur al-Junoubi, Beirut, Dār İhyā al-Turāth al-'Arabì.

Ibn A'tham. 1411 A.H. Al-Futūh, Beirut, Dār al-Nadveh.

Ibn Athir, 'Izz al-Din Abu al-Hassan. 1408 AH. Al-Kāmil fì al-tārīkh, Beirut, Dār Īhyā al-Turāth al-'Arabī.

Shetreet, S. (1999). Between Three Branches of Goverment: The Balance of Rights in Matters of Religion in Israel. Floersheimer: Institute Publications.

Ṭabarī, Muḥammad ibn Jarīr, Tarikh al-Umam wa al-Muluk, 1967 A.D. Research: Muhammad Abu al-Fazl Ibrahim, Dār al-Turāth, Beirut.

Users, N. T. O. (2010). Note to users. Cornell Hotel and Restaurant Administration Quarterly, 22, 64-64.

Vukovic, S. 2014 A.D. "International mediation as a distinct form of conflict management", International Journal of Conflict Management, Vol. 25 No. 1, pp. 61-80.

\section{Copyrights}

Copyright for this article is retained by the author(s), with first publication rights granted to the journal.

This is an open-access article distributed under the terms and conditions of the Creative Commons Attribution license (http://creativecommons.org/licenses/by/4.0/). 